паралінгвістичних чинників, правил поведінки фахівця, урахування професійної ситуації спілкування тощо» [4, с. 171].

Використання всіх зазначених аспектів у процесі мовної підготовки студентів лісотехнічного напряму навчання забезпечить належний рівень фахових лінгвістичних знань, що сприятиме успішності в майбутній професійній діяльності.

Отже, дослідження найважливіших аспектів мовної підготовки студентів лісотехнічного напряму навчання, аналіз навчальних програм, а також результати анкетування студентів обгрунтовують доцільність розвитку й удосконалення термінологічної компетентності, що дозволяє зробити висновок про необхідність створення методики навчання фахової термінології, упровадження якої в навчальний процес підвищить якість професійної компетентності майбутніх інженерів лісотехнічної та деревообробної галузей і сприятиме розвитку їх мотивації у навчанні української мови як засобу ділової комунікації.

\title{
Література
}

1. Артикуца Н. В. Мова права i юридична термінологія : [навч. посіб.] [Електронний ресурс] / Н. В. Артикуца. - К. : Стилос, 2004. - Режим доступу до докум. : http://en.kul.kiev.ua/ praci-2004-roku/artikuca-n.-v.-mova-prava-i-juridichnaterminologija-navchalniy-posibnik.html 2. Артикуца Н. В. Про нові підходи до мовної підготовки майбутніх юристів і викладачів права у вищих навчальних закладах України : препринт [Електронний ресурс]/ Н. В. Артикуца. - Режим доступу до докум. : $\quad$ http://www.ekmair.ukma.kiev.ua/handle/123456789/2456 3. Булик-

Верхола С. 3. Основи термінознавства : [навч. посіб.] / С. З. Булик-Верхола, Г. В. Наконечна, Ю. В. Теглівець. - Львів : Видавництво Львівської політехніки, 2013. - 160 с. 4. Дроздова І. П. Наукові основи формування українського професійного мовлення студентів нефілологічних факультетів ВНЗ : [монографія] / І. П. Дроздова ; Харк. нац. акад. міськ. госп-ва. - Х. : ХНАМГ, 2010. - 320 с. 5. Кочан І. М. Словникдовідник з методики викладання української мови / І. М. Кочан, Н. М. Захлюпана. - [2-е вид., випр. і доп.]. - Львів : Видавничий центр ЛНУ ім. Івана Франка, 2005. - 306 с. 6. Полковенко Т. В. Навчальна програма дисципліни «Основи термінознавства» (для бакалаврів) [Електронний ресурс] / Т. В. Полковенко. - К. : МАУП, 2009. - 26 с. - Режим доступу до докум. : http://library.iapm.edu.ua/ metod_disc/Pdf/4195_osn_temin.pdf

$$
\text { УДК 378:37.011.3-051]:5 }
$$

Олена Лаврентьєва

\section{МЕТОДИКА РОЗВИТКУ МЕТОДОЛОГІЧНОЇ КУЛЬТУРИ МАЙБУТНІХ УЧИТЕЛІВ ПРИРОДНИЧИХ ДИСЦИПЛІН У ПРОЦЕСІ ПРОФЕСІЙНОЇ ПІДГОТОВКИ}

Лаврентьєва О. О. Методика розвитку методологічної культури майбутніх учителів природничих дисциплін у процесі професійної підготовки.

У статті розкрито основні концептуальні положення методики розвитку методологічної культури майбутнього вчителя природничих дисциплін. Методику представлено як упорядковану сукупність алгоритмів, процедур, етапів, комплексу педагогічних умов, форм, засобів і прийомів, форм і видів професійно-педагогічної підготовки, що спрямовуються на наскрізну загальну та спеціальну методологічну підготовку й цілеспрямований розвиток у майбутнього вчителя методологічної культури.

Ключові слова: методика, професійна підготовка вчителя природничих 
дисциплін, методологічна культура вчителя, структура методологічної культури, методологічна підготовка.

Лаврентьева Е. А. Методика развития методологической культуры будущих учителей естественных дисциплин в процессе профессиональной подготовки.

В статье раскрываются основные концептуальные положения методики развития методологической культуры будущего учителя естественнонаучных дисциплин. Методика представлена как упорядоченная совокупность алгоритмов, процедур, этапов, комплекса педагогических условий, форм, средств и приемов, форм и видов профессионально-педагогической подготовки, которые направлены на сквозную общую и специальную методологическую подготовку, на целенаправленное развитие у будущего учителя методологической культуры.

Ключевые слова: методика, профессиональная подготовка учителя естественных дисциплин, методологическая культура учителя, структура методологической культуры, методологическая подготовка.

Lavrentyeva O. A. Methodology of development of the methodological culture of the future teachers of natural disciplines in the process of professional preparation.

The substantive conceptual provisions of the methods of development of the Science teacher's methodological culture is shown in the article. Science teacher's methodological culture and this phenomenon is given both broad and narrow interpretations according to the level of a teacher's methodological activity formation. A specific educative way of thinking is determined as a system-forming factor of the methodological culture. Methodics is presented as a well-organized totality of algorithms, procedures, stages, complex of pedagogical terms, forms, facilities and receptions, forms and types of professionallypedagogical training process, that are aimed at the end to provide general and special methodological training, on purposeful development for the future Sciences teacher of methodological culture.

Key words: methodology, professional preparing of teacher of natural disciplines, methodological culture of teacher, structure of methodological culture, methodological preparation.

Як результат осмислення змісту професійної діяльності вчителя, який на сучасному етапі виконує функції викладача, вихователя, методиста й дослідника педагогічної реальності, виходить на рівень проектування й конструювання педагогічних систем, виокремлюється новий культурний феномен - методологічна культура вчителя.

Однак, незважаючи на те, що в історії педагогіки і вищої школи започатковано традиції світоглядно-методологічної підготовки вчителя, склалася концепція і було створено систему професійної підготовки вчителів природничих дисциплін, потребує розв'язання низка нагальних питань. Кожен дослідник, залежно від завдань та напряму розроблення, подає своє бачення сутності методологічної культури вчителя, iii місця і ролі в метасистемі професійно-педагогічної культури, впливових чинників їі формування i розвитку. I якщо для провідних фахівців, авторів наукових шкіл, методологів педагогіки - Е. Абдулліна, Є. Бондаревської, М. Бургіна, Г. Валєєва, С. Гончаренка, В. Краєвського, С. Кульневича, В. Семиченко, В. Сластьоніна, О. Ходусова та інших - важливим $€$ теоретичне узагальнення, виокремлення стратегічних ідей, актуального складу методологічної культури вчителя, то решта 
робіт (О. Бережнова, О. Бойко, Ю. Глаголєва, М. Дубова, С. Казанцев, В. Кириллов, В. Кравцов, В. Мосолов та інші) орієнтується на завдання конкретного педагогічного дослідження й не надає визначених стратегій розвитку методологічної культури майбутнього вчителя.

Метою статті є відображення основних концептуальних положень методики розвитку методологічної культури майбутніх учителів природничих дисциплін у процесі професійної підготовки.

Узагальненням наших теоретичних розробок окресленої проблеми $є$ образ методологічної культури вчителя, що був покладений в основу проектування методики іiі розвитку. Уважаємо, що методологічна культура визначає здатність учителя до певного способу пізнання та фіксації явищ в ідеальному плані, до критикорефлексивного аналізу процесу формування й інтеграції змісту знань, професійнопедагогічної діяльності та власного саморозвитку, їх прогнозування і творчого перетворення на світоглядних i культурологічних засадах сучасної науки й педагогічної практики.

Методологічну культуру інтерпретуємо як у широкому, так і вузькому значенні. У широкому значенні це культура педагога-дослідника, що свідомо займається управлінням і конструюванням професійно-педагогічної діяльності. Методологічна культура у вузькому значенні відображує специфічну для галузі освіти культуру мислення, що потрібна вчителеві для розв'язання професійно-педагогічних проблем у галузі педагогічної теорії і практики. Зважаючи на ціннісно центрований характер культури, системоутворювальним чинником методологічної культури визначаємо специфічний для системи освіти стиль мислення- визначені i сформовані та інтеріоризовані орієнтири, що становлять регулятивно-ціннісну основу мислення вчителя.

Розвиток методологічної культури розглядаємо як поступальний рух, еволюцію, перехід від одного стану до іншого, як генезу - утворення і становлення компонентів методологічної культури, їх інтеграції, виокремлення системоутворювального чинника, визначення місця в метасистемі професійно-педагогічної культури, що розгортається в часі, за змістом, обсягом і спрямуванням. Доцільною інтерпретацією цієї ідеї є модель Б. Гершунського: грамотність $\rightarrow$ освіченість $\rightarrow$ компетентність $\rightarrow$ культура [2].

Методику розвитку методологічної культури майбутніх учителів природничих дисциплін представляємо як упорядковану сукупність алгоритмів, процедур, етапів. У цьому визначенні підкреслюємо близькість розроблюваної методики до технології, однак при цьому наголошуємо на суттєвій відмінності: методика описує на логічному рівні конкретну діяльність 3 розвитку методологічної культури, не представляючи іiі процедурно, як у технології.

Основними функціями методики вважаємо:

- методологічну, оскільки вона визначає цілі, завдання, принципи, зумовлює методи і засоби, а також логіку розвитку методологічної культури майбутнього вчителя;

- управлінську - формулює засоби планування, організації, мотивації, координації та контролю з боку викладачів за процесом становлення, формування та розвитку методологічної культури студентів у системі професійної підготовки;

- проективно-конструктивну, за допомогою якої відбувається переведення наявних теоретичних розробок на реальні освітні технології розвитку методологічної культури студентів; 
- критеріально-оцінну, оскільки забезпечує розробку критеріїв і оцінку ступеня й напряму розвитку методологічної культури студентів відповідно до застосованих засобів.

Виходячи із провідної мети нашого дослідження, формулюємо ієрархію изілей розвитку методологічної культури майбутнього вчителя природничих дисциплін у процесі професійної підготовки:

1) становлення методологічної грамотності студентів;

2) формування i нарощування мотиваційно-ціннісного, інтелектуальногностичного, діяльнісно-практичного i творчо-рефлексивного компонентів методологічної культури майбутнього вчителя;

3) формування методологічної компетентності як основи професійнопедагогічної компетентності;

4) розвиток компонентів методологічної культури як складників професійнопедагогічної культури, становлення специфічного для сфери освіти стилю мислення майбутнього вчителя природничих дисциплін;

5) інтеграція компонентів i розвиток методологічної культури як стрижня професійно-педагогічної культури майбутнього вчителя природничих дисциплін.

В основу розвитку методологічної культури покладаємо систему з загальних і спеціальних принщипів. До групи загальних принципів відносимо: принципи гуманізації й гуманітаризації, професійної спрямованості, принципи науковості і фундаменталізації, наступності, індивідуалізації й диференціації, принцип культурної детермінації підготовки майбутнього вчителя, принцип фасилітації, інтеграції освіти, науки і педагогічної практики. Група специфічних принципів поєднує в собі ті, що відображають специфіку розвитку методологічної культури, причому в майбутніх учителів природничих дисциплін. Ця група охоплює:

- принцип раціогуманізму [1], який зумовлює максимальне використання багатства інтелектуальної культури в тї гармонійній взаємодії 3 гуманітарною культурою майбутніх учителів та іншими складниками професійно-педагогічної культури задля розширення знань про природу, суспільство, людину та їх гуманістично орієнтованого практичного застосування під час творчого перетворення студентами педагогічної реальності;

- принцип логізації змісту професійної підготовки, що означає приведення всіх їі компонентів у системно-структурну відповідність, виокремлення змістовнозначеннєвих, методологічних координат, усвідомлення необхідності збагнення зв'язків і кореляції різних галузей педагогічної і природничих наук, їх проблемної організації [3];

- принцип проблемно-методологічного структурування навчального матеріалу, що передбачає спеціальну побудову навчального матеріалу, додання йому цільової орієнтації на методологічне оброблення наукової інформації;

- принцип формування методологічної діяльності студентів і викладачів, що передбачає процес поступового передавання виконання окремих елементів діяльності самому студентові, а в педагогічному управлінні процесом розвитку методологічної культури - перехід від безпосереднього й жорсткого до опосередкованого і гнучкого його видів;

- принцип культуровідповідності, що зумовлює орієнтацію професійної підготовки майбутнього вчителя на цінності, зміст і характер гуманітарної культури, традиційної для українського суспільства та природничо-наукової культури, характерної для постіндустріального суспільства; 
- принцип активізації методологічної рефлексії, який виявляється в самовизначенні студентами цілей діяльності, зумовлює обгрунтований вибір форм i методів досягнення цілей, самоаналіз і порівняння отриманих результатів 3 поставленою метою; самооцінку й самокорекцію;

- принцип циклічності передбачає орієнтацію на необхідність нелінійного бачення процесу розвитку методологічної культури й забезпечення поглиблення, розширення змісту їі компонентів;

- принцип саморозвитку, що інтегрує систему фундаментальних принципів розвитку особистості і передбачає перехід у фазу усвідомлюваної, цілеспрямованої, переважно внутрішньо детермінованої діяльності щодо ініціювання якісних i кількісних змін у структурі методологічної культури.

Засобами розвитку методологічної культури майбутнього вчителя природничих дисциплін $\epsilon$ : педагогічні технології, методи i форми професійної підготовки, використовувані за певною тактикою - із застосовуванням певних методологічних орієнтирів. 3-поміж них особливо доцільними є: культурологічний, гуманістичний, когнітивний, компетентнісний, ціннісно-орієнтаційний, особистісно-діяльнісний, проблемний, задачний, діалогічний, імітаційно-ігровий, міждисциплінарний, контекстний, системний, синергетичний, ресурсний підходи.

Як показали наші дослідження, найбільш доцільними засобами розвитку методологічної культури майбутніх учителів природничих дисциплін $\epsilon$ :

- когнітивні, креативні й оргдіяльнісні методи навчання;

- метод схематичного моделювання - шляхи і способи розумового оперування знаннями, усвідомлення внутрішньої архітектоніки мислення, оформлення процесу оволодіння поняттями й категоризації знань у вигляді образотворчих схем (мислесхем, схематизацій, структурних схем, структурно-логічних схем, Інтелекткарт, кластерів і асоціативних кущів, схем-опор, опорних конспектів, хронокарт, мережевих графіків, діаграм, графіків тощо), а також процедури реалізації методу шляхом підведення під поняття, категоризації й схемотехніки; методу;

- метод проектів у форматі педагогічної технології і комплексного навчального

- інтерактивні технології і методи, зокрема: технології кооперативного навчання, колективно-групового навчання, ситуативного навчання, опрацювання дискусійних питань, а також превентивних, імітаційних і неімітаційних інтеракцій;

- кейс-метод - спосіб активного навчання, що містить неоднозначні імовірнісні знання, які виявляються під час аналізу практичної ситуації, i який з успіхом інтегрується 3 іншими провідними педагогічними технологіями i методами інтерактивними, імітаційно-ігровими, проблемними, комунікативними, продуктивними, відеометодом;

- методологічний семінар - спеціальний тип організації навчального процесу, що одночасно реалізує функції семінару й лекції; форми і методу навчання, забезпечує обговорення значного обсягу теоретичної інформації в поєднанні із практичними вправами, обмін досвідом і технологіями між його учасниками, залучення їх до відрефлексованої методологічної роботи;

- IКТ та інтернет-ресурси, спрямовані на формування інтернет-культури студента в навчально-методичному, ціннісно-мотиваційному й методологічному контекстах;

- науково-дослідницька діяльність майбутніх учителів, 3 якою власне i асоціюється становлення і розвиток методологічної культури педагога-дослідника; 
- система узагальнювальних спецкурсів («Формування професійної творчості вчителя», «Методика педагогічної взаємодії», «Формування професійно-педагогічної культури майбутнього вчителя»), доцільних для підтримки поетапного розвитку методологічної культури студентів.

Процедурна частина методики розвитку методологічної культури майбутнього вчителя природничих дисциплін має бути забезпечена методичним пакетом, що містить необхідні рекомендації для викладачів та студентів, розроблені навчальні плани i програми, діагностувальні матеріали для оцінки й діагностування досліджуваної якості.

Формування і розвиток методологічної культури $є$ тривалим процесом, у якому можна визначити певні етапи. Ірунтуючись на роботах дослідників окресленої проблеми (О. Бережнової, Г. Валєєва, П. Кабанова, В. Кравцова, О. Ходусова та інших), визначаємо такі:

1-й - ознайомлення 3 методологічними проблемами під час засвоєння базових дисциплін професійної підготовки і становлення методологічної грамотності майбутніх учителів.

2-й - засвоєння знань стосовно шляхів розв'язання методологічних проблем i формування у студентів методологічної компетентності.

3-й- формування вмінь створювати й застосовувати методологічні знання, оволодіння рівнями однозначної й багатозначної детермінації, діалектичним рівнем і рівнем цілісного підходу- формування методологічної культури майбутнього вчителя.

4-й - інтеграція і розвиток компонентів методологічної культури.

Ураховуючи необхідність забезпечення педагогічного управління цим процесом, визначаємо таку методику розвитку методологічної культури майбутнього вчителя у процесі професійної підготовки:

I. Підготовчий еman - I-II курс, його мета: обгрунтування методики розвитку методологічної культури майбутнього вчителя природничих дисциплін. Змістом етапу є:

1.Вивчення стану проблеми у практиці роботи педагогічного ВНЗ, обгрунтування чинників розвитку, суперечностей $\mathrm{i}$ труднощів розвитку методологічної культури майбутнього вчителя.

2. Опрацювання нормативних документів, навчальних планів та програм, визначення особливостей професійної підготовки майбутнього вчителя природничих дисциплін, виявлення методологічного інваріанта компонентів професійної підготовки.

3. Структурування змісту базових навчальних дисциплін i виокремлення складників методологічної підготовки. студентів.

4. Діагностування наявного рівня розвиненості методологічної культури

5. Створення системи роботи й дослідно-експериментальної програми розвитку методологічної культури майбутніх учителів.

Засобами, що визначають напрями пошуків, $\epsilon$ : стандарти професійної підготовки, навчальні плани і програми, методичні рекомендації до викладання дисциплін наскрізної методологічної підготовки, діагностувальні методики.

II. Формувальний eman - II-III курси, його мета: ознайомлення студентів 3 основними методологічними проблемами, становлення компонентів методологічної культури майбутнього вчителя природничих дисциплін, його методологічної грамотності засобами прямого управління. 
Змістом етапу є:

1. Підготовка і практична реалізація методичного інструментарію становлення методологічної культури студентів на заняттях із базових дисциплін із використанням механізмів рефлексії.

2. Розроблення й апробація пропедевтичних спецкурсів із розвитку методологічної компетентності майбутнього вчителя.

3. Створення та запровадження педагогічного супроводу самостійної та науководослідницької роботи студентів.

4. Педагогічний моніторинг складників методологічної культури студентів.

Засобами формування методологічної культури $є$ : предметний $\mathrm{i}$ практичний аспекти змісту дисциплін базового навчального плану, інтегровані і пропедевтичні спецкурси, «пасивна» педагогічна практика, еталонні моделі професійної поведінки, дослідницька діяльність, науково-дослідна робота, проблемні, когнітивні, оргдіяльнісні й інтерактивні методи, технології групової роботи, навчальні проекти, кейси, схематичне моделювання, евристичні приписи, педагогічні задачі, інтернетресурси.

III. Розвивальний етап - III-IV курси, його мета: формування основ професійнопедагогічної компетентності, розвиток компонентів методологічної культури як складників професійно-педагогічної культури майбутнього вчителя природничих дисциплін засобами опосередкованого управління. Змістом етапу є:

1. Підготовка і практична реалізація методичного інструментарію розвитку методологічної культури студентів на заняттях із дисциплін професійного спрямування, під час навчальної й педагогічної практики із використанням механізмів рефлексії.

2. Створення й запровадження педагогічного супроводу науково-дослідницької діяльності студентів.

3. Розроблення методичних підходів до читання інтегрованих курсів та спецкурсів з розвитку методологічної культури майбутніх учителів.

4. Педагогічний моніторинг компонентів методологічної культури студентів.

Засобами розвитку методологічної культури $\epsilon$ : науковий, методичний i практичний аспекти змісту дисциплін професійного спрямування, активна педагогічна практика, навчальна практика, курсові дослідження, методологічні семінари, еталонні моделі професійно-педагогічної компетентності, когнітивні, креативні та оргдіяльнісні методи, інтерактивні, продуктивні, проблемні, ігрові технології, ІКТ, тематичні конференції, самостійна навчальна діяльність, науководослідницька діяльність.

IV. Контрольно-коригувальний етап - V курс (магістри і спеціалісти), його мета: формування професійно-педагогічної культури, інтеграція компонентів і розвиток методологічної культури як стрижня професійно-педагогічної культури майбутнього вчителя природничих дисциплін з урахуванням специфіки ОКР. Змістом етапу є:

1. Вивчення стану проблеми формування професійно-педагогічної культури майбутнього вчителя природничих дисциплін, обгрунтування чинників розвитку, суперечностей і труднощів.

2. Розроблення й реалізація програми розвитку методологічної культури майбутнього вчителя 3 урахуванням специфіки ОКР із використанням механізмів рефлексії.

3. Створення й запровадження педагогічного супроводу науково-дослідної діяльності студентів, підготовки й захисту кваліфікаційних досліджень. 
4. Розроблення методичних підходів до читання узагальнювальних інтегрованих курсів із розвитку методологічної культури майбутніх учителів.

5. Контрольний діагностувальний зріз рівня розвиненості методологічної культури студентів.

Засобами коригування розвитку методологічної культури $\epsilon$ : науковий, практичний і методологічний аспекти змісту дисциплін професійного спрямування, узагальнюючих спецкурсів, навчальна i педагогічна практики, еталонні моделі професійно-педагогічної культури, лекторії, методологічні семінари, тренінгові заняття, науково-практичні конференції, практикуми, інтерактивні, ігрові, продуктивні, дистанційні, рефлексивно-розвивальні технології, ІКТ, технології розвитку критичного мислення, науково-дослідницька діяльність, кваліфікаційні дослідження.

Ефективність розвитку методологічної культури майбутніх учителів природничих дисциплін на кожному 3 етапів має забезпечуватися комплексом педагогічних умов. До них ми віднесли: готовність викладачів до становлення у студентів специфічного для галузі освіти стилю мислення, посилення наскрізної загальної та спеціальної методологічної підготовки, використання механізмів методологічної рефлексії у сприйнятті, розумінні, проектуванні й конструюванні майбутніми вчителями педагогічної реальності, педагогічний моніторинг стану педагогічної системи розвитку методологічної культури майбутнього вчителя природничих дисциплін.

Методика розвитку методологічної культури майбутнього вчителя природничих дисциплін повинна бути побудованою на основі таксономії цілей іiї розвитку; передбачати навчання методології дослідницької та інноваційної діяльності й методологічної рефлексії у процесі формування у студентів образу професійнопедагогічної діяльності, її методичного, дидактичного, виховного, методологічного та іншого аспектів. Уважаємо, що становлення й розвиток методологічної культури визначається узгодженим, системним характером загальнокультурного, загальнонаукового, фундаментального, психолого-педагогічного, практичного й методологічного складників підготовки майбутніх учителів, у процесі засвоєння курсів, що мають «домінантну» методологічну спрямованість та «наскрізних» компонентів педагогічної освіти - самостійної роботи, науково-дослідницької діяльності, навчальної й педагогічної практик, кваліфікаційних досліджень. Цей процес повинен перебувати в органічній єдності та інтегрально характеризувати цілі, зміст, етапи та рівні професійної підготовки майбутніх учителів, пріоритетні напрями педагогіки вищої школи й галузевої науки.

\section{Література}

1. Балл Г. А. Психология в рациогуманистической перспективе: избр. работы / Георгий Александрович Балл. - К. : Основа, 2006. - 408 с. 2. Гершунский Б. С. Образование в третьем тысячелетии: гармония знания и веры / Б. С. Гершунский // Педагогика. - 1998. - № 2. - С. 49-57. 3. Кириллов В. К. Методологическая культура учителя, ее формирование в учебном процессе педвуза / В. К. Кириллов // Новые исследования в педагогических науках. - М., 1991.- Вып. 1/57. - С. 75-78. 4. Ходусов А. Н. Формирование методологической культуры учителя : дис. ... д-ра пед. наук : 13.00.08 / Ходусов Александр Николаевич. - М., 1997. - 430 с. 